\title{
水素化燃焼合成法による $\mathrm{Mg}_{2} \mathrm{FeH}_{6}$ および $\mathrm{Mg}_{2} \mathrm{CoH}_{5}$ の合成
}

\author{
大辻貴久 ${ }^{1, *}$ 秋山友宏 ${ }^{2}$ 八木順一郎 1 \\ 1東北大学素材工学研究所 \\ 2 大阪府立大学大学院工学研究科 \\ J. Japan Inst. Metals, Vol. 64, No. 8 (2000), pp. 656-661 \\ (C) 2000 The Japan Institute of Metals
}

\section{Hydriding Combustion Synthesis of $\mathrm{Mg}_{2} \mathrm{FeH}_{6}$ and $\mathrm{Mg}_{2} \mathrm{CoH}_{5}$}

Takahisa Ohtsuji ${ }^{1, *}$, Tomohiro Akiyama ${ }^{2}$ and Jun-ichiro Yagi ${ }^{1}$

Institute for Advanced Materials Processing, Tohoku University, Sendai 980-8577

${ }^{2}$ Graduate School of Engineering, Osaka Prefecture University, Sakai 599-8531

Metallic hydrides of $\mathrm{Mg}-\mathrm{Fe}$ and $\mathrm{Mg}-\mathrm{Co}$ systems are quite attractive as a hydrogen storage alloy for their large storage capacity; 5.5 mass\% in $\mathrm{Mg}_{2} \mathrm{FeH}_{6}$ and 4.5 mass\% in $\mathrm{Mg}_{2} \mathrm{CoH}_{5}$. However, the production of $\mathrm{Mg}_{2} \mathrm{Fe}$ and $\mathrm{Mg}_{2} \mathrm{Co}$ alloys before hydriding has been difficult due to their unstable phases.

The purpose of this study is to directly produce the metallic hydrides of $\mathrm{Mg}-\mathrm{Fe}$ and $\mathrm{Mg}$-Co using the hydriding combustion synthesis. With this method, the pre-production process of intermetallic compounds can be eliminated. Well-mixed and compressed metallic powders are heated in hydrogen atmosphere and then the chemical compositions of the products are identified by $\mathrm{X}$-ray diffraction analysis.

As a result, pure metallic hydrides are successfully obtained by controlling hydrogen pressure, heating and compressing conditions. These results also give a possibility for an innovative production process of $\mathrm{Mg}_{2} \mathrm{FeH}_{6}$ and $\mathrm{Mg}_{2} \mathrm{CoH}_{5}$.

(Received March 30, 2000; Accepted July 6, 2000)

Keywords: hydrogen storage alloy, hydriding combustion synthesis, $\mathrm{Mg}_{2} \mathrm{FeH}_{6}, \mathrm{Mg}_{2} \mathrm{CoH}_{5}$

\section{1. 緒言}

高容量水素吸蔵合金として $\mathrm{Mg}-\mathrm{Ni}$ 系合金の実用化が切望 されている．この Mg-Ni 系の理論水素吸蔵量は 3.6 mass\% $\left(\mathrm{Mg}_{2} \mathrm{NiH}_{4}\right)$ であるが，本研究で検討する $\mathrm{Mg}-\mathrm{Fe}$ 系抒よび $\mathrm{Mg}-\mathrm{Co}$ 系の理論吸藏量はそれぞれ 5.5 mass\% $\left(\mathrm{Mg}_{2} \mathrm{FeH}_{6}\right)$ 和よび 4.5 mass\% $\left(\mathrm{Mg}_{2} \mathrm{CoH}_{5}\right)$ であり大変鬽力的である。し かし $\mathrm{Mg}_{2} \mathrm{Fe}$ 㧊よび $\mathrm{Mg}_{2} \mathrm{Co}$ が安定相として存在しないため, それらの金属水素化物の製造法が確立されていないのが現状 である1,2)。

一方, 败焼合成法3-5) 法の一つであり，一般に(1)低製造ェネルギー，(2)高純度生成 物, (3)簡易装置, (4)瞬間合成, (5)準安定相合成可, (6)生成物 形状制御可, 等の数多くの利点がある.水素化燃焼合成法の 原理は粒径の小さい原料粉末を湿式混合することにより両者 の接触面積を極限まで高め，その圧粉成形体を水素雾团気中 以掠き加熱することにより固体一固体一気体反応を単一プロ セスで行らことにある。現在有望視される $\mathrm{Mg}-\mathrm{Ni}$ 系におい ては水素化燃焼合成法を用いること年らり，従来法で不可欠 な活性化処理は不要となり高純度な金属水素化物

\footnotetext{
* 東北大学大学院生 (Graduate Student, Tohoku University)
}

$\left(\mathrm{Mg}_{2} \mathrm{NiH}_{4}\right)$ を得ることに成功している6-12).

そこで本研究で性省亦ルギー型 $\mathrm{Mg}-\mathrm{X}(\mathrm{X}=\mathrm{Fe}, \mathrm{Co})$ 系水 素吸蔵合金製造法の開発を目的と乙，合成時们和る保持時 間, 水素厈怙上び圧粉成形王の保持時間を変兄, 燃燒合成 に上り実験的に水素化物を得ること学試みた。とくに $\mathrm{Mg}_{2} \mathrm{FeH}_{6}$ は $\mathrm{Mg}_{2} \mathrm{NiH}_{4}$ より水素吸藏量が1.5倍も大きく $\mathrm{Fe}$ は原料価格の点から有利であるため, 新規製造法開発の工業 的意義は極めて大さい。

\section{2. 実験}

\section{1 試 料}

試料は金属粉末を混合，摚拌，成型，粉碚することにより 準備した。詳細は磯貝らによる $\mathrm{Mg}-\mathrm{Ni}$ 系燃焼合成法の研 究6) と同様である. Table 1 亿示す粉末試薬をモル比で $\mathrm{Mg}$ ： $\mathrm{Fe}$ あるいは $\mathrm{C}=2: 1$ の割合に秤量した後，アセトン中に 投入し超音波ホモジナイザーを用い混合した。室温下で試料

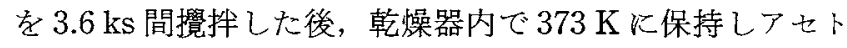
ンを蒸発除去した。最後汇混合試薬の密着性を高めるために ダイスにより一方向加圧で $1.1 \mathrm{MPa}$ の荷重をかけ円柱形(直 径 $10 \mathrm{~mm} \times$ 高さ $5 \mathrm{~mm}$ ) 飞成型したが，このと加圧成形時

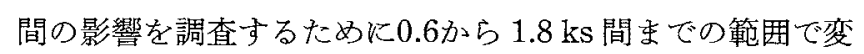
化させた。燃焼合成実験では成型体学乳鉢で約 $500 \mu \mathrm{m}$ 以下 
Table 1 Chemicals used in this study.

\begin{tabular}{lcc}
\hline & $\begin{array}{c}\text { Purity } \\
\text { (mass\%) }\end{array}$ & $\begin{array}{c}\text { Powder size } \\
(\mu \mathrm{mn})\end{array}$ \\
\hline $\mathrm{Mg}$ & 99.9 & Less than 177 \\
$\mathrm{Fe}$ & 99 up & 2 to 3 \\
$\mathrm{Co}$ & 99 up & 5 \\
\hline
\end{tabular}

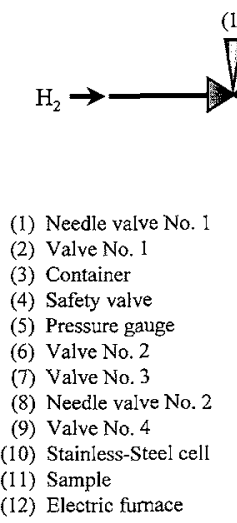

(12) Electric fumace

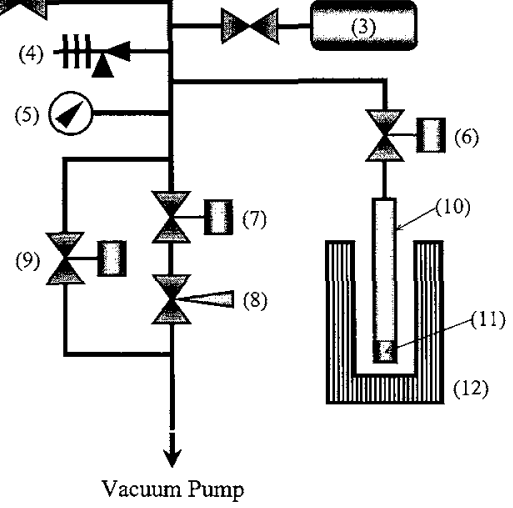

Fig. 1 Schematic diagram of experimental apparatus for synthesis.

Table 2 Experimental conditions.

\begin{tabular}{lcccc}
\hline No. & $\begin{array}{c}\text { Holding time } \\
\text { at specified } \\
\text { temperature } \\
(\mathrm{ks})\end{array}$ & $\begin{array}{c}\text { Hydrogen } \\
\text { pressure } \\
(\mathrm{MPa})\end{array}$ & $\begin{array}{c}\text { Compression } \\
\text { time } \\
(\mathrm{ks})\end{array}$ & $\begin{array}{c}\text { Holding } \\
\text { temperature } \\
(\mathrm{K})\end{array}$ \\
\hline 1$)$ & $3.6,18,36$ and 180 & 9 & 0.6 & \\
\hline 25 & 36 & $3,5,7$ and 9 & 0.6 & $\begin{array}{c}773(\mathrm{Mg}-\mathrm{Fe}) \\
723(\mathrm{Mg}-\mathrm{Co})\end{array}$ \\
\hline 3$)$ & 18 & 9 & $0.6,7.2$ and 18 & \\
\hline
\end{tabular}

に粉砕し使用した。

\section{2 実験方法}

燃焼合成実験にはPCT 特性測定装置を使用した．Fig. 1 はその概略図である。密閉型ステンレス製セル(内径 4.3 $\mathrm{mm}$, 高さ $280 \mathrm{~mm}$ ) 中に, 粉砕した試料を $0.5 \mathrm{~g}$ 挿入し, 真 空度 $1.33 \times 10^{-4} \mathrm{~Pa}$ まで吸引した。 その後, 電気炉を用い $20 \mathrm{~K} / \mathrm{min}$ で所定の温度まで昇温し, 水素がス(純度 $99.99999 \mathrm{~mol} \%$ ) 導入した。 Table 2 は本研究に打ける実 験条件である．合成に影響を与える因子として1）保持時 間，2）水素平拉よび3）圧粉成形圧の保持時間が予想される ため，これらの值を変觉実験を行った．保持温度が合成に大 さく影響を及ぼすことは明らかであるが，ここでは焼結法で 既に報告がある Selvam とYvonの研究13) と最終的に比較す る目的で $\mathrm{Mg}-\mathrm{Fe}$ 系 $773 \mathrm{~K}, \mathrm{Mg}-\mathrm{Co}$ 系 $723 \mathrm{~K}$ とした。水素 ガスを導入してから所定時間が経過した後,ただちに試料セ ルを電気炬から引き上げ室温まで泠却した。 その後取り出し た生成物を粉末 X線回折法により組成を同定した。同時に 走査型電子影微鏡 $(\mathrm{SEM})$ を用いて試料の微視的観察を行っ た。

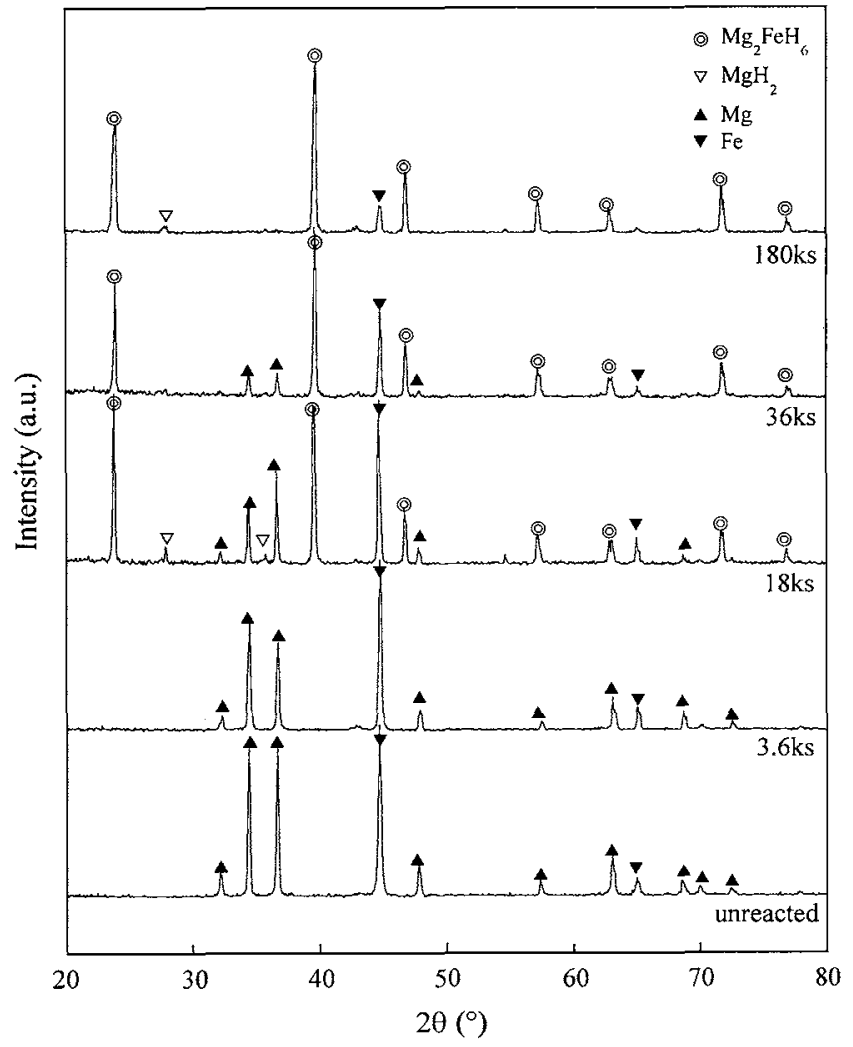

Fig. 2 Effect of holding time at the temperature of $773 \mathrm{~K}$ on $\mathrm{X}$-ray diffraction patterns of the products, after $\mathrm{Mg}-\mathrm{Fe}$ samples were kept for different times under $9 \mathrm{MPa}$ hydrogen atmosphere.

\section{3. 結 果と考察}

\section{1 加熱保持時間の影響}

Fig. 2 和よびFig. 3 にそれぞれ Mg-Fe 执よび Mg-Co 系 に扣いて所定温度に扣子る保持時間を变化させた場合に得ら れた生成物の X 線回折結果を示す. $\mathrm{Mg}-\mathrm{Fe}$ 系では保持時間 が長くなるにつ礼目的の水素化物である $\mathrm{Mg}_{2} \mathrm{FeH}_{6}$ のピーク が明確になり，180 ks 時間保持したもので住高純度の水素 化物が合成された。このケースではわずかに Fe のピークが

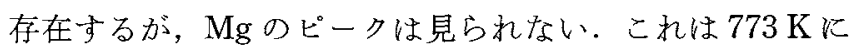
長時間保持したため，蒸気压の大きな $\mathrm{Mg}$ が一部揮発した ためであると推察される。

$\mathrm{Mg}-\mathrm{Co}$ 系比和いて子同様の傾向が見られるが，短時間保 持した試料では $\mathrm{MgH}_{2}$ の比較的大きなピークが現れ時間と ともに減少した。これらの結果は $\mathrm{Mg}-\mathrm{Fe}$ 系では直接 $\mathrm{Mg}_{2} \mathrm{FeH}_{6}$ が合成されるが， $\mathrm{Mg}-\mathrm{Co}$ 系に特いては $\mathrm{MgH}_{2}$ 経由して目的生成物の $\mathrm{Mg}_{2} \mathrm{CoH}_{5}$ が合成されることを示して Wる.

これらの系ではいずれも $180 \mathrm{ks}$ 時間わの長時間保持後に 目的生成物が合成された。これは瞬間的に生成物が得られる Mg-Ni 系然然合成とは極端に異なっている。その理由は， 1) 反応炕よる発熱量が小さいこと，特よび，2） $\mathrm{Mg}_{2} \mathrm{Fe}$ 物よ び $\mathrm{Mg}_{2} \mathrm{Co}$ が存在しないことが主原因と推察される。また， $\mathrm{Mg}-\mathrm{Ni}, \mathrm{Mg}-\mathrm{Fe}$ および $\mathrm{Mg}-\mathrm{Co}$ 系の状態図 ${ }^{14)}$ からわかるよ ら飞 $\mathrm{Mg}-\mathrm{Ni}$ 系では金属間化合物 $\mathrm{Mg}_{2} \mathrm{Ni}$ が存在し，共晶温 


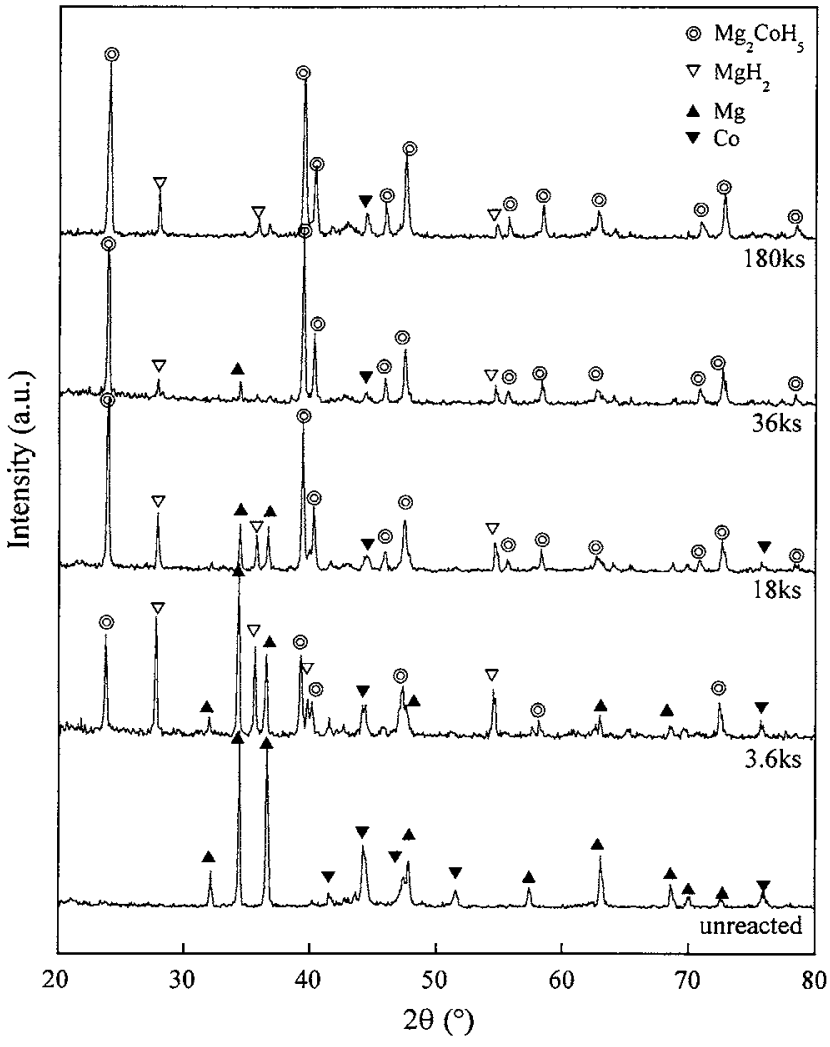

Fig. 3 Effect of holding time at the temperature of $723 \mathrm{~K}$ on $\mathrm{X}$-ray diffraction patterns of the products, after $\mathrm{Mg}$-Co samples were kept under $9 \mathrm{MPa}$ hydrogen atmosphere for different times.

度において液相が発生するため反応速度が大幅に上昇した が, $\mathrm{Mg}-\mathrm{Fe}$ 扝よび $\mathrm{Mg}-\mathrm{Co}_{0}$ 系活いては金属間化合物 $\mathrm{Mg}_{2} \mathrm{Fe}$ 牤よび $\mathrm{Mg}_{2} \mathrm{Co}$ 快存在しないため反応を加速する要因 が存在しない、したがって，Mg-Fe 叔よび $\mathrm{Mg}-\mathrm{Co}_{0}$ 系燃焼 合成は $\mathrm{Mg}-\mathrm{Ni}$ 系とは根本的に異なることが予想される。こ のよらな遅い反応系を改善する方法として他の燃燒反応系と 組み合わせる方法が有望であり，今後の課題と位置づけられ る.

\section{2 印加水素圧力の影響}

Fig. 4 执よびFig. 5 にそれぞれ Mg-Fe 㸬よび Mg-Co 系 に和いて印加水素圧を変化させ所定の温度に保持した時得ら れた生成物の X 線回折結果を示す. $\mathrm{Mg}-\mathrm{Fe}$ 系では $3 \mathrm{MPa}$ 扣よび $5 \mathrm{MPa}$ に括いては水素化物のピークが汪とんど確認

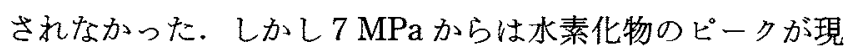
れ，9 MPa 飞和いては $\mathrm{Mg}_{2} \mathrm{FeH}_{6}$ の明確なピークが確認でき た.

一方, $\mathrm{Mg}-\mathrm{Co}$ 系では水素圧が低い酒ど目的の水素化物 $\left(\mathrm{Mg}_{2} \mathrm{CoH}_{5}\right)$ とは異なる水素化物 $\mathrm{Mg}_{3} \mathrm{CoH}_{5}$ (理論水素吸蔵量 3.7 mass\%)のピークが強く現れた。これ注粒子が $\mathrm{Mg}$ と Co のモル比 2:1に十分汾散して扮らず，局所的にその比率 が不均一であったことに由来すると推察される.水素の压力 上昇とともに $\mathrm{Mg}_{3} \mathrm{CoH}_{5}$ のピークは低下し, $\mathrm{Mg}_{2} \mathrm{CoH}_{5}$ のピ 一ク強度は上昇し, 最終的に $9 \mathrm{MPa}$ 飞扮いては他の水素化 物は生成せず，高純度の $\mathrm{Mg}_{2} \mathrm{CoH}_{5}$ が得られることが判明し

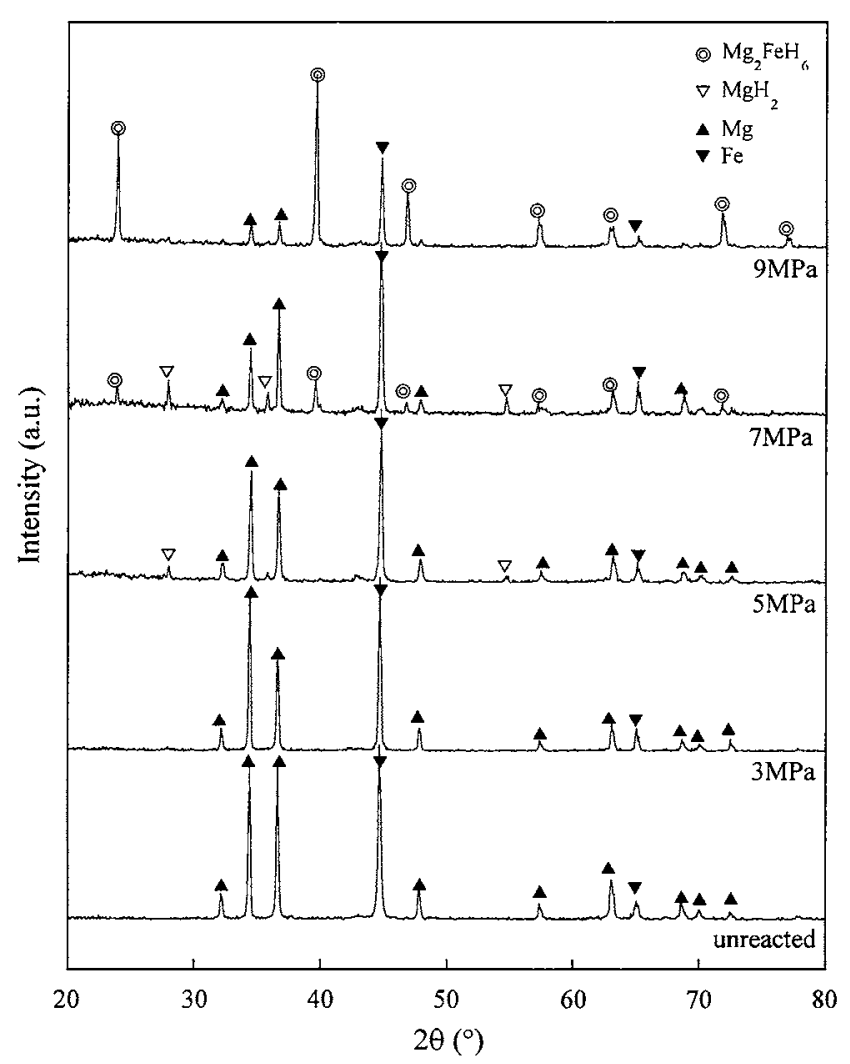

Fig. 4 Effect of hydrogen pressure on X-ray diffraction patterns of the products, after $\mathrm{Mg}-\mathrm{Fe}$ samples were kept at 773 $\mathrm{K}$ for $36 \mathrm{ks}$.

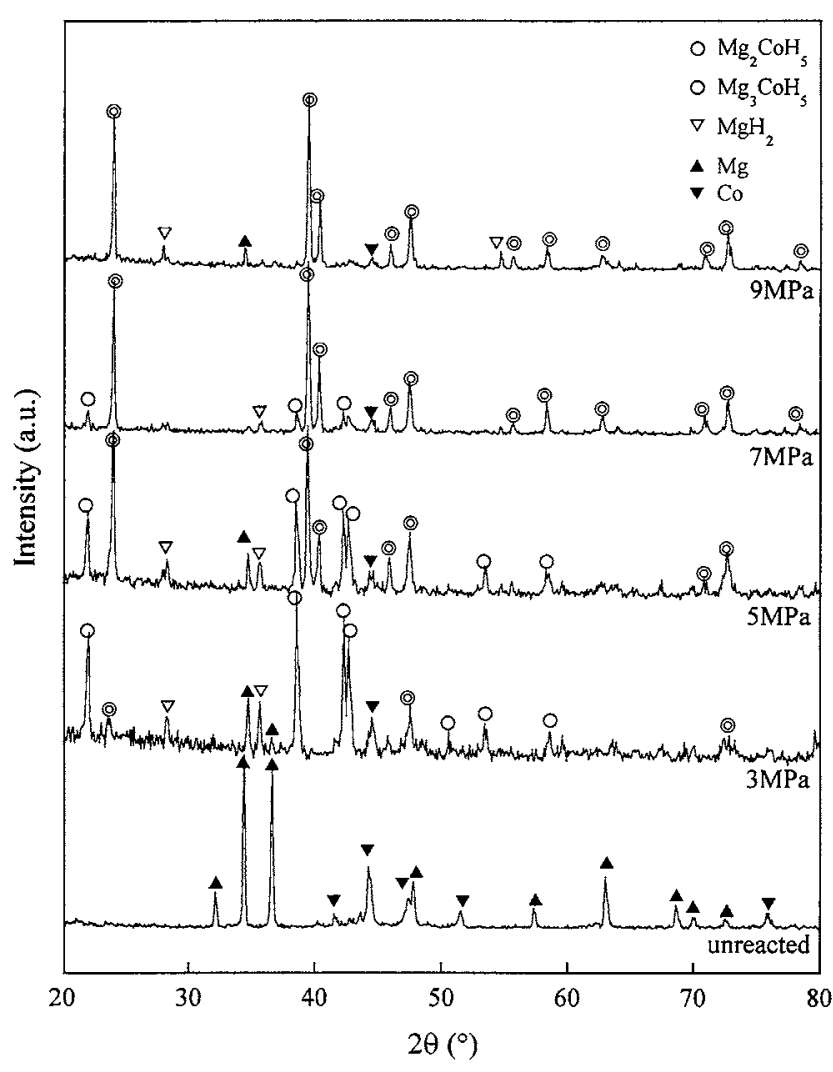

Fig. 5 Effect of hydrogen pressure on X-ray diffration patterns of the products after $\mathrm{Mg}$-Co samples were kept at $723 \mathrm{~K}$ for $36 \mathrm{ks}$. 


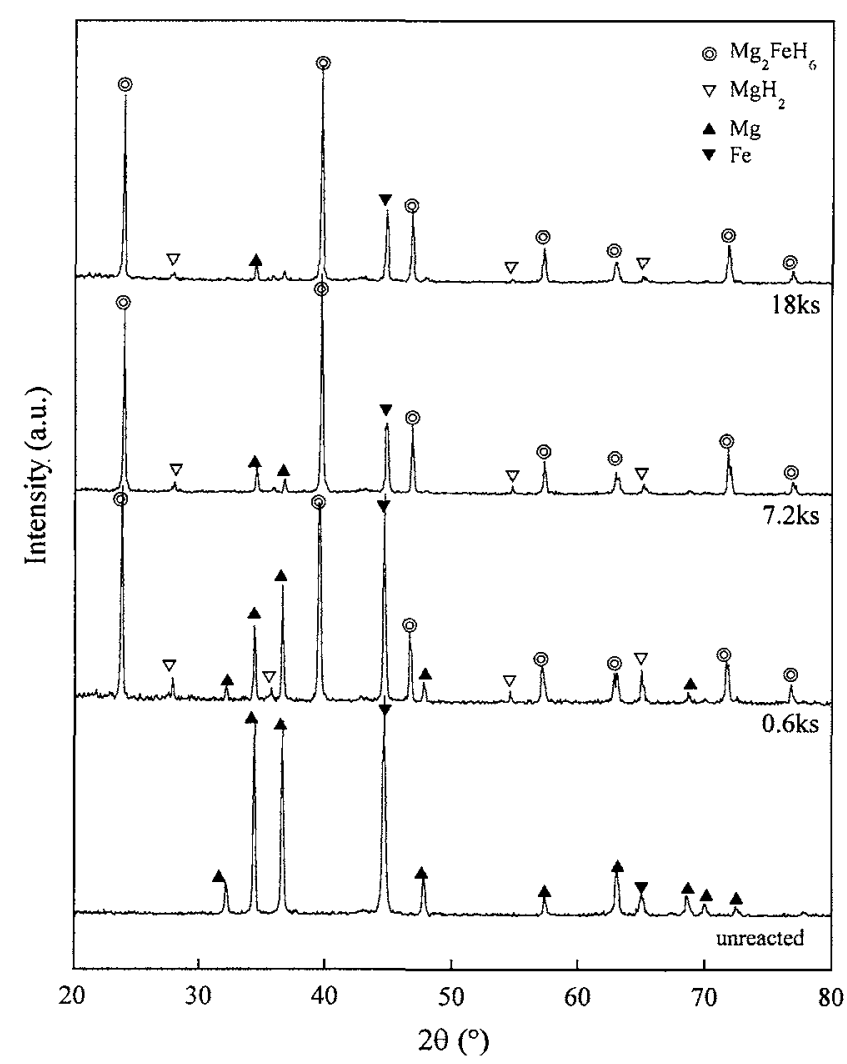

Fig. 6 Effect of sample compression time on X-ray diffraction patterns of the products, after $\mathrm{Mg}-\mathrm{Fe}$ samples were kept at $773 \mathrm{~K}$ for $18 \mathrm{ks}$ under $9 \mathrm{MPa}$ hydrogen.

た。

\section{3 圧粉成型時間の影響}

Fig. 6 および Fig. 7 にそれぞれ $\mathrm{Mg}-\mathrm{Fe}$ 扣よび $\mathrm{Mg}-\mathrm{Co}$ 系 に和いて圧粉成型時間を変化さ得られた生成物のX線回 折結果を示す. $\mathrm{Mg}-\mathrm{Fe}, \mathrm{Mg}-\mathrm{Co}$ 両系とも長時間王粉したも のほど，生成物中の原料試薬のピークが減少していく傾向が 確認された.このことから，試料作成時の王粉時間は水素化 の反応速度に大きく影響を与えることが判明した。

しかし両系とも， $7.2 \mathrm{ks}$ 执よび $18 \mathrm{ks}$ 時間成型圧を保持し た試料についてはX 線解析の結果に曊著な違いが見られな いことから，成型圧保持時間の影響は一定時間以降は小さい ことがわかる。この現象は長時間の圧粉により， Fe, Co 粒 子の周りで比較的大きく柔らかい $\mathrm{Mg}$ 粒子の表面が時間之 ともに変形を起こし粒子同士の密着が促進されることが原因 であると推察できる。また類似の現象として，成型压の保持 時間が熱伝尊率に顕著な影響を及湆すことが報告されてい $ろ^{15)}$.

成型圧保持時間を变化させた試料の SEM たよる組織観察 写真を Fig. 8 和よび Fig. 9 に示す。これらの写真は $0.6 \mathrm{ks}$ 時間圧粉した試料に比べ， $7.2 \mathrm{ks}$ 時間または $18 \mathrm{ks}$ 時間开粉 した試料に招污る原料粉末の密着性が向上していることを示 した。

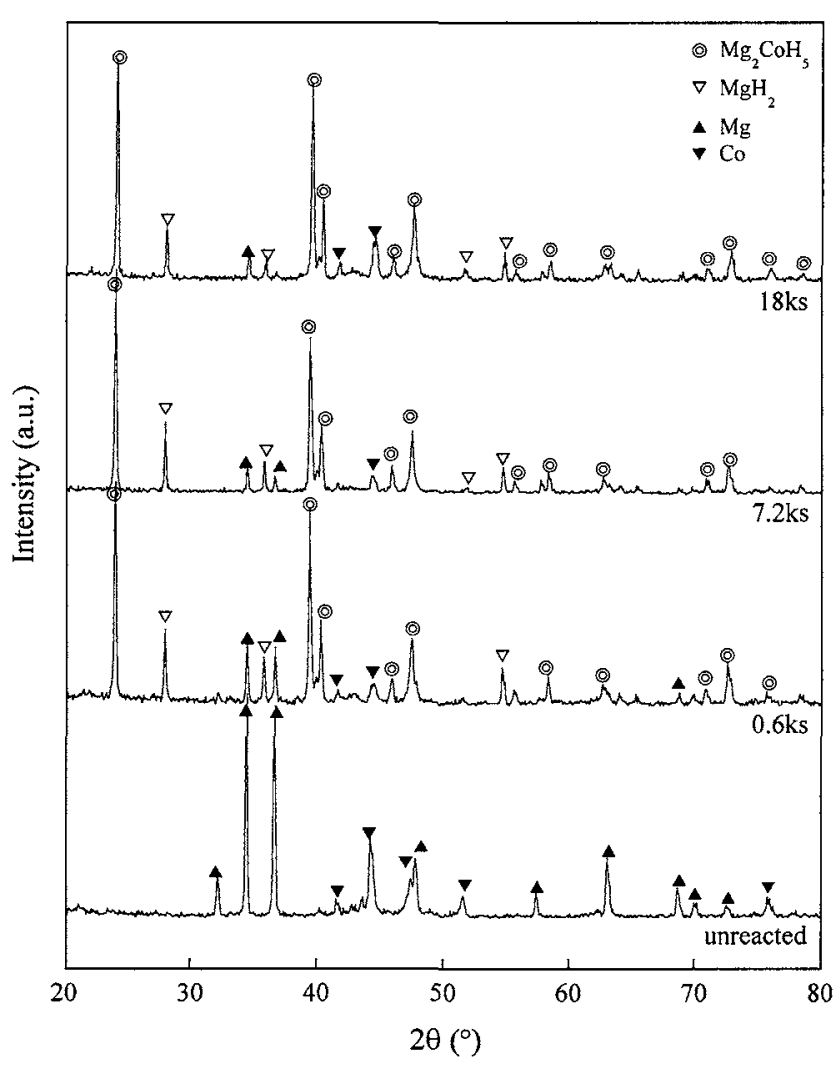

Fig. 7 Effect of sample compression time on X-ray diffraction patterns of the products, after $\mathrm{Mg}$-Co samples were kept at $723 \mathrm{~K}$ for $18 \mathrm{ks}$ under $9 \mathrm{MPa}$ hydrogen.

然瑨合成法による $\mathrm{Mg}-\mathrm{X}(\mathrm{X}=\mathrm{Fe}, \mathrm{Co})$ 系水素化物の新規合 成の可能性について検討した. PCT 特性測定装置を用いた 然筞合成実験，X線回折による組成分析和よび SEM を用い た組織観察を行い以下の結論を得た。

（1）金属粉を湿式混合した試料を高圧水素雾团気下で加熱 することにより，単一プロセスで高純度の $\mathrm{Mg}_{2} \mathrm{FeH}_{6}$ 拈よび $\mathrm{Mg}_{2} \mathrm{CoH}_{5}$ を合成でさる。

（2）得られた生成物の純度は加熱状熊に保持する時間叔上 び印加水素王の影響を強く受ける. 水素王が $9 \mathrm{MPa}$ 以上の 高生下で, $\mathrm{Mg}-\mathrm{Fe}$ 系は $773 \mathrm{~K}, \mathrm{Mg}-\mathrm{Co}$ 系は $723 \mathrm{~K}$ に扣ける 保持時間が $180 \mathrm{ks}$ 時間以上の条件では，高純度の $\mathrm{Mg}_{2} \mathrm{FeH}_{6}$ 特よび $\mathrm{Mg}_{2} \mathrm{CoH}_{5}$ が合成される。

（3）水素化の反応速度を大きくするためには玨粉成型の加 王保持時間を十分に長く取る必要がある。

本研究により, $\mathrm{Mg}-\mathrm{X}(\mathrm{X}=\mathrm{Fe}, \mathrm{Co})$ 系水素吸蔵合金の水素 化物合成には，高い水素圧 $(9 \mathrm{MPa})$ が必要であるが，高純度 の水素化物が合成可能であることを明らかにした。今後仕こ 水 $5 \mathrm{Mg}-\mathrm{X}(\mathrm{X}=\mathrm{Fe}, \mathrm{Co})$ 系水素吸蔵合金の反応機構を解明 し，実用化に向けたプロセス設計を行う必要がある。 

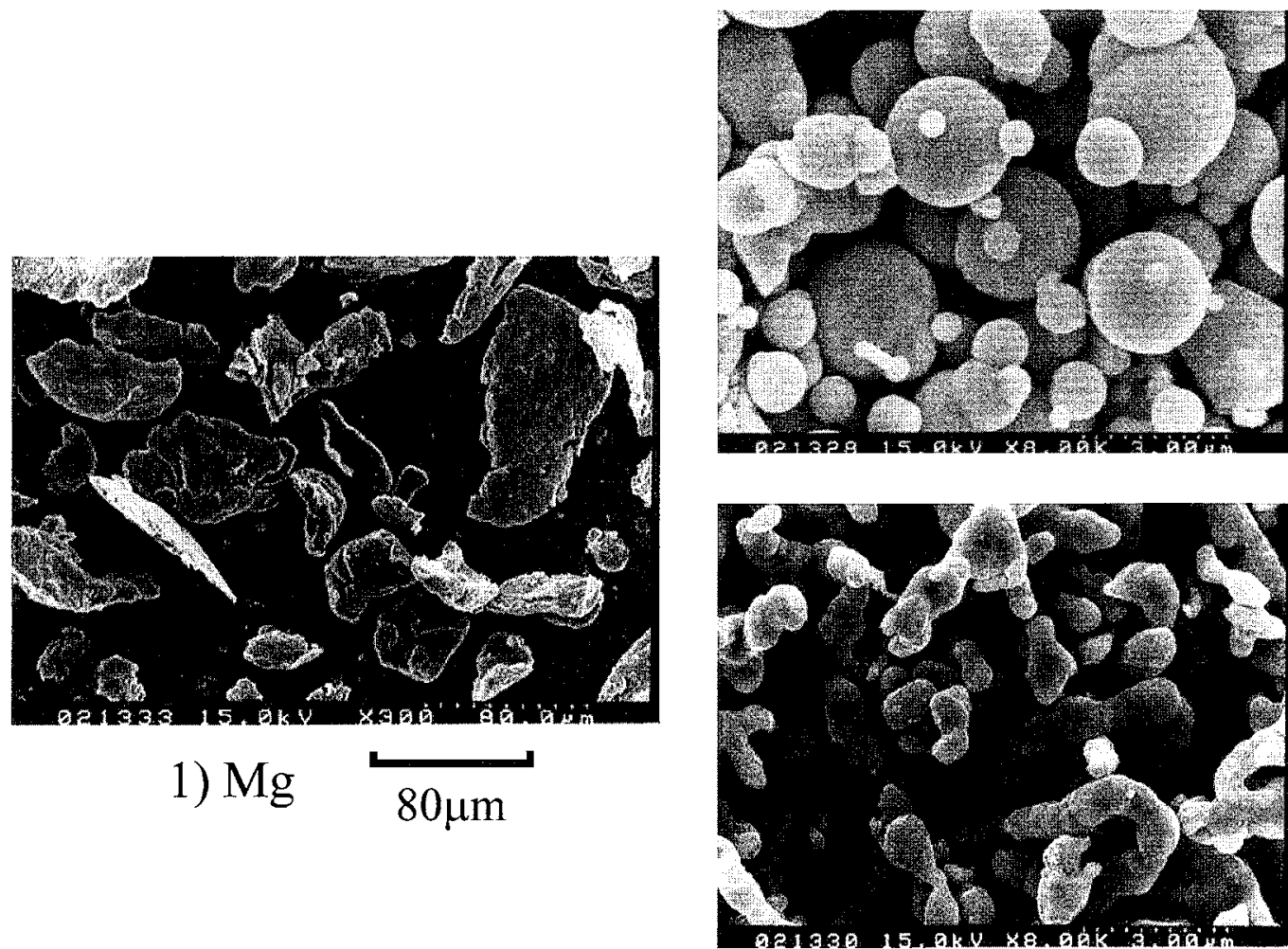

2) $\mathrm{Fe}$

3) $\mathrm{Co}$

Fig. 8 SEM photographs of raw samples.

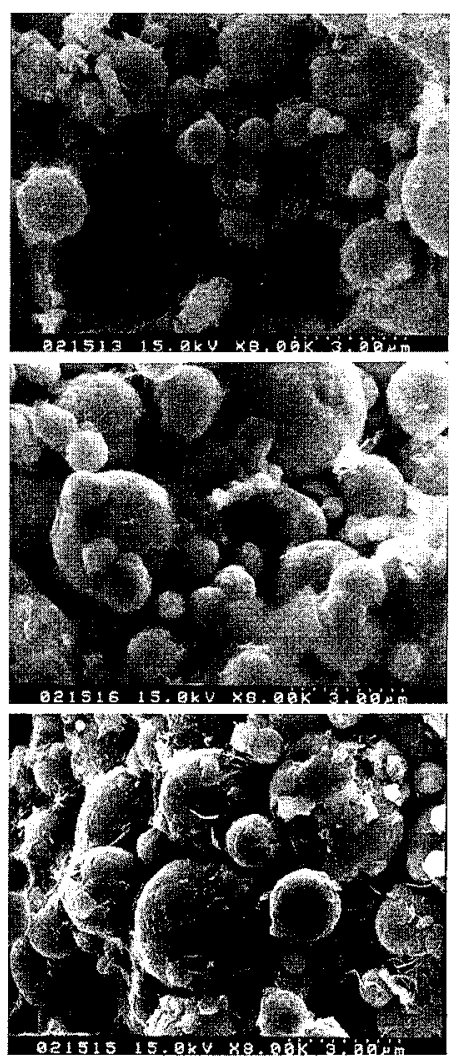

1) $\mathrm{Mg}-\mathrm{Fe}$ (a) Compressed for $0.6 \mathrm{ks}$.

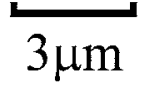

(b) Compressed for $7.2 \mathrm{ks}$

(c) Compressed for $18 \mathrm{ks}$.
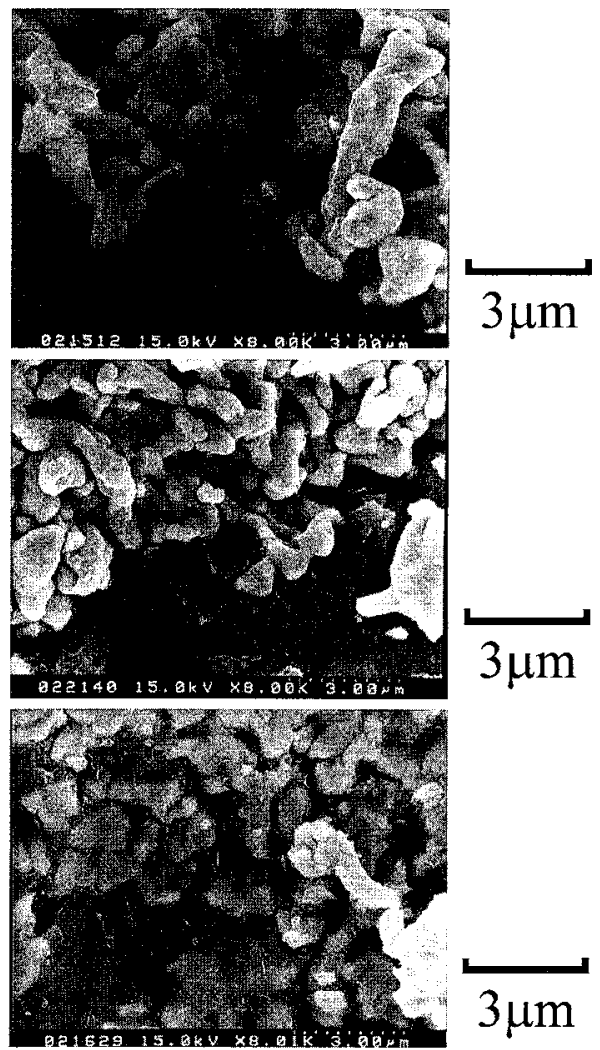

2) $\mathrm{Mg}-\mathrm{Co}$

Fig. 9 SEM photographs of compressed samples. 
研究は文部省科学研究費 (B09450276, B10450282), トヨタ 先端科学研究プログラム(1999) 特よびホソカワミクロン粉 体研究助成(1999)により行われた。記して謝意を表す。

\section{文献}

1) J. Huot, H. Hayakawa and E. Akiba: J. Alloys Comp., 248 (1997), 164-167.

2) J. Huot, S. Boily, E. Akiba and R. Schulz: J. Alloys Comp. 280 (1998), 306-309.

3) A. Varma and J. P. Lebrat: Chem. Eng. Sci., 47(1992), 2179.

4) A. G. Merzhnov: Int. J. Self-Propagating High-Temperature Synthesis, 2(1993), 113.

5) Z. A. Munir: Met Trans. A, 23A(1992), 7.

6) H. Isogai, T. Akiyama and J. Yagi: J. Japan Inst. Metals, 60(1996), 338-344.
7) H. Isogai, T. Akiyama and J. Yagi: J. Japan Inst. Metals, 60 (1996), 640-645.

8) H. Isogai, T. Akiyama and J. Yagi: J. Japan Inst. Metals, 60(1996), 647-652.

9) H. Kohno, T. Akiyama, S. Kobayashi and J. Yagi: J. Japan Inst. Metals, 61(1997), 166-170.

10) Liquan Li, T. Akiyama, T. Kabutomori, K. Terao and J. Yagi: J. Alloys Comp., 281(1998), 175-180.

11) Liquan $\mathrm{Li}, \mathrm{T}$. Akiyama and J. Yagi: Intermetallics, 7(1998), 201-205.

12) S. Nagashima, T. Akiyama and J. Yagi: J. Japan Inst. Metals, 12(1999), 1555-1560.

13) P. Selvam and K. Yvon: Int. J. Hydrogen Energy, 16(1991), 615.

14) A. A. Nayeb-Hashemi, L. J. Swartzendruber and J. B. Clark: Phase Diagrams of Binary Magnesium Alloys, ASM INTERNATIONAL, (1988).

15) T. Akiyama, T. A. Tazaki, R. Takahashi and J. Yagi: Intermetallics, 4(1996), 659-662. 